\title{
Porcine Epidemic Diarrhea Virus
}

National Cancer Institute

\section{Source}

National Cancer Institute. Porcine Epidemic Diarrhea Virus. NCI Thesaurus. Code C121657.

An alphacoronavirus that infects the cells lining the small intestine of the pig. It is the causative agent of porcine epidemic diarrhea. 